\title{
DOES THE HIGH ELEVATION CLIMATE ALONG MT. EVEREST CAN BE REPRESENTED BY LOWER ELEVATION STATIONS?
}

\author{
Binod Dawadi1,2,*, Shankar Sharma1, Kalpana Hamal ${ }^{3,4}$, Nitesh Khadka, ${ }^{4,5}$, Yam Prasad Dhital ${ }^{6}$, Shiva Kumar \\ Mahato $^{7}$ \\ ${ }^{1}$ Central Department of Hydrology and Meteorology, Tribhuvan University, Kathmandu \\ ${ }^{2}$ Kathmandu Center for Research and Education, Chinese Academy of Sciences-Tribhuvan University, Kathmandu 44613, Nepal \\ ${ }^{3}$ International Centre for Climate and Environment Sciences, Institute of Atmospheric Physics, Chinese Academy of Sciences, P.O. Box \\ 9804, Beïing 100029, China \\ ${ }^{4}$ University of Chinese Academy of Sciences, Beijing 100049, China \\ ${ }^{5}$ Institute of Mountain Hazards and Environment, Chinese Academy of Sciences, Chengdu 610041, China \\ ${ }^{6}$ School of water and architecture engineering, Shibezi University, Shihezi, China \\ ${ }^{7}$ Department of Meteorology, Trichandra Campus, Tribhuvan University, Kathmandu \\ *Corresponding author: binod.dawadi@cdhm.tu.edu.np \\ (Received: November 04, 2021; Revised: December 12, 2021; Accepted: December 14, 2021)
}

\begin{abstract}
Climate change studies of the high mountain areas of the central Himalayan region are mostly represented by the meteorological stations of the lower elevation. Therefore, to validate the climatic linkages, daily observational climate data from five automated weather stations (AWS) at elevations ranging from $2660 \mathrm{~m}$ to $5600 \mathrm{~m}$ on the southern slope of Mt. Everest were examined. Despite variations in the means and distribution of daily, 5-day, 10-day, and monthly temperature and precipitation between stations located at a higher elevation and their corresponding lower elevation, temperature records in the different elevations are highly correlated. In contrast, the precipitation data shows a comparatively weaker correlation. The slopes of the regression model $(0.82-1.13)$ with $\left(\mathrm{R}^{2}>0.74\right)$ for higher altitude $(5050 \mathrm{~m}$ and $5600 \mathrm{~m})$ throughout the year, 0.83-1.12 $\left(\mathrm{R}^{2}>0.68\right)$ except late monsoon season for the station at $4260 \mathrm{~m}$ and $5050 \mathrm{~m}$ asl indicated the similar variability of the temperature between those stations. Similarly, Namche (3570 m) temperature changes by $0.81-1.32^{\circ} \mathrm{C}$ per degree change in corresponding lower elevation Lukla station (2660 m), except for monsoon season. However, inconsistent variation was observed between the station with a large altitudinal difference $(2940 \mathrm{~m})$ at Lukla and Kala Patthar $(5600 \mathrm{~m})$. In general, climate records from corresponding lower elevation can be used to quantitatively assess climatic information of the high elevation areas on the southern slope of Mt. Everest. However, corrections are necessary when absolute values of climatic factors are considered, especially in snow cover and snow-free areas. This study will be beneficial for understanding the high-altitude climate change and impact studies.
\end{abstract}

Keywords: Climate change, climatic linkage, elevational gradient, Mt Everest

\section{INTRODUCTION}

The intrinsic characteristics of precipitation and temperature vary over space and time (Shrestha et al., 2000; Chalise \& Khanal, 2002). Within a short latitudinal difference, climate in high-elevation areas varies significantly from the nearby low-elevations areas (Sharma et al., 2021). Topographic-induced dynamic and thermodynamic processes can modify the synoptic weather systems and create regional-scale atmospheric circulation (Li et al., 2020; Wang et al., 2020). Such regimes generate a distinct wind system, cloudiness, and precipitation patterns and lead to a peculiar mountain climate (Shrestha et al., 2019b; Xu et al., 2019). However, temperature and precipitation variability at high altitudes are very limited compared to lower elevation areas. The remote location and difficulty in routine maintenance of automated weather stations (AWS) create complications for obtaining long-term climate measurements, especially at high elevations (Sabatini, 2017). Furthermore, the complex topographic nature coupled with unique mountain climate often needs area-specific measurements
(Dawadi, 2017) because it may not represent true mountain climatology.

The Himalayas and mountains represent $\sim 80 \%$ of the total area of Nepal. These mountains are the unique area for detecting climatic change and assessing climateinduced impacts (Beniston, 2003; Khadka et al., 2018) . A wide range of altitudinal variations in the Himalayas and surrounding areas amplifies the climatic variation in the region (Liu \& Chen, 2000; Thompson et al., 2000) . Therefore, local observations are required to determine the nature of climate variability at high elevation and identify the impact of climate change and their teleconnections with global climate change (Seidel \& Free, 2003). The analysis of climate change's impact on the environment/glaciers/hydrology of the Himalayas is even more complicated due to the high variability in temperature and precipitation. Although reanalysis and satellite products also provide climatic records, in-situ gauge observation provides the true measurement of climatic variables at the earth's surface (Sun et al., 2018; 
Hamal et al., 2020c). Department of Hydrology and Meteorology (DHM), the Government of Nepal maintains and distributes the climatic record in Nepal; however, these gauge observations are denser in southern lowlands and sparse in northern high-elevation areas (Sharma et al., 2020a). The lack of observation in the Himalayan region creates large uncertainties in climate change projection and the climatic response on glaciers (Shea et al., 2015). Moreover, insufficient in situ measurements from the high altitudes of the Himalayas create a gap in our understanding of the precipitation and temperature pattern as well as the state of a glacier in the context of climate change(King et al., 2017; Thakuri et al., 2019; Sharma et al., 2020b) .

Several studies have recently examined the temperature and precipitation trend over the Himalayas and surrounding high altitude regions (Yue et al., 2019; Hamal et al., 2020a; Shrestha et al., 2021). Moreover, these studies indicate that the annual temperatures have generally increased in the region (Shrestha \& Devkota, 2010; Shrestha \& Aryal, 2011; Dibike et al., 2012; Kattel et al., 2013; Thakuri et al., 2019), and experiencing higher increase rates of temperature than the global average $(\mathrm{Li}$ et al., 2011; Poudel et al., 2020). In the Himalayas, annual precipitation trends appear to be heterogeneous and relatively weak (Kansakar et al., 2004; Salerno et al., 2015; Karki et al., 2017; Shrestha et al., 2019a; Talchabhadel et al., 2018; Hamal et al., 2020b). Besides, many studies have shown the dynamics of snow and retreat of Himalayan glaciers in the recent decades in response to change in temperature and precipitation (Yao et al., 2012; King et al., 2017; Khadka et al., 2020b). Most of these studies are based on in-situ data directly or indirectly from the lower elevation (generally below $2600 \mathrm{~m}$ asl.). Moreover, the temporal and spatial records of DHM meteorological observation at Himalayan areas are very scarce compared to other mountain regions, such as the European Alps (Shea et al., 2015) . In addition, most of the available observatories at a high-elevation area are located at valley bottoms (Ueno \& Aryal, 2008; Dawadi et al., 2013; Liang et al., 2015; Krishnan et al., 2019). Such sparse and irregular distributed meteorological stations across the country limit our understanding of high mountain climates(Bohner, 2006; Shea et al., 2015).

Climatology of the region varies based on space and time, especially over the complex mountain terrain. The climatic linkages between the different altitudes provide vital information; however, such information depends on the region's local climate and physiography (Dawadi et al., 2020). Further, our knowledge about the possibilities of using low-elevation climatic data to represent highelevation climates is very limited. Furthermore, it is of growing concern that can the data from the meteorological stations at a lower elevation well represent the climatic scenarios of the high-elevation Himalayas or not? Thus, this study aims to answer whether the lower elevation station represents the climatology of the higher elevation station. More specifically, this study aims to analyze the climatic linkage along the altitudinal gradient of Central Himalaya, i.e., Mt. Everest region. To meet the objective, we have selected climatological records (temperature and precipitation) from five AWS stations ranging from $2650 \mathrm{~m}$ asl to $5600 \mathrm{~m}$ asl to analyze the climatic linkage. This study will be very important for understanding the linkage of lower and higher elevation climates, understanding high-elevation climatology.

\section{MATERIALS AND METHODS}

\section{Study area and climatology}

The highest five observational stations from Lukla (2660 $\mathrm{m}$ asl), Namche Bazar (3570 $\mathrm{m}$ asl), Pheriche (4260 $\mathrm{m}$ asl), Pyramid (5050 $\mathrm{m}$ asl), and Kala Patthar (5600 m asl) located along the elevational gradient of the Mt Everest are selected for the current study (Fig. 1). These five automatic weather stations (AWS) are selected based on two criteria, i.e., climatic stations above $2600 \mathrm{~m}$, and the altitudinal difference between stations is higher than 550 $\mathrm{m}$. The study area hosts four world's highest mountain peaks: Mount Everest (Sagarmatha in Nepali, $8849 \mathrm{~m}$ ), Cho You (8188 m), Makalu (8485 m), and Lhotse (8516 m) (Khadka et al., 2020a). The elevation, geographic location, mean temperature, and annual total rainfall of these five stations are presented in Table 1.

The climate of the study region is characterized by distinct seasonality of both precipitation and temperature (Shea et al., 2015). Monthly variations of temperature and precipitation based on observation from 2003 to 2012 showed that July is the month with the highest precipitation except in Pyramid (August) and the hottest except Namche Bazar (June) (Fig. 2). The annual average temperature ranges from $3.4^{\circ} \mathrm{C}$ to $14.4^{\circ} \mathrm{C},-0.6^{\circ} \mathrm{C}$ to $10.8^{\circ} \mathrm{C},-6.9^{\circ} \mathrm{C}$ to $7.7^{\circ} \mathrm{C},-7.9^{\circ} \mathrm{C}$ to $3.5^{\circ} \mathrm{C}$, and $-11.8^{\circ} \mathrm{C}$ to $0.9^{\circ} \mathrm{C}$, respectively for Lukla, Namche Bazar, Pheriche, Pyramid, and Kala Patthar. The annual precipitation decreases with an increase in elevation from $1612 \mathrm{~mm}$, $1182 \mathrm{~mm}, 442 \mathrm{~mm}, 364 \mathrm{~mm}$ for Lukla, Namche Bazar, Pheriche, and Pyramid; however, precipitation in Kala Patthar is slightly higher $(386 \mathrm{~mm})$ than the Pyramid. This region receives the highest precipitation $(\sim 83 \%)$ during the monsoon season (June-September), while postmonsoon (October-November) and pre-monsoon (March-May) seasons jointly contribute $\sim 13.5 \%$ of annual precipitation. The winter (December-February) is the driest season, with around $\sim 3.5 \%$ of the total precipitation (Fig. 2).

\section{Data source and method}

Department of Hydrology and Meteorology (DHM), Government of Nepal (https://www.dhm.gov.np) operates, maintains, and distributes hydro-meteorological data of the observed stations across the country. However, 
due to the logistics, technological difficulties, and routine maintenance of observation networks, especially in remote areas of high elevation, most stations are established below 2500 masl. Therefore, to understand the climatic linkage along the elevation gradient of Mt. Everest, we took advantage of the high-elevation stations from the
SHARE project of Ev-K2-CNR, Italy. Verified and calibrated high-quality daily datasets from Lukla, Namche Bazar, Pheriche, Pyramid, and Kala Patthar were collected from Ev-K2-CNR, Italy (Table 1). These stations are jointly established and run by the Nepal Academy of Science and Technology (NAST) and Ev-K2-CNR, Italy.

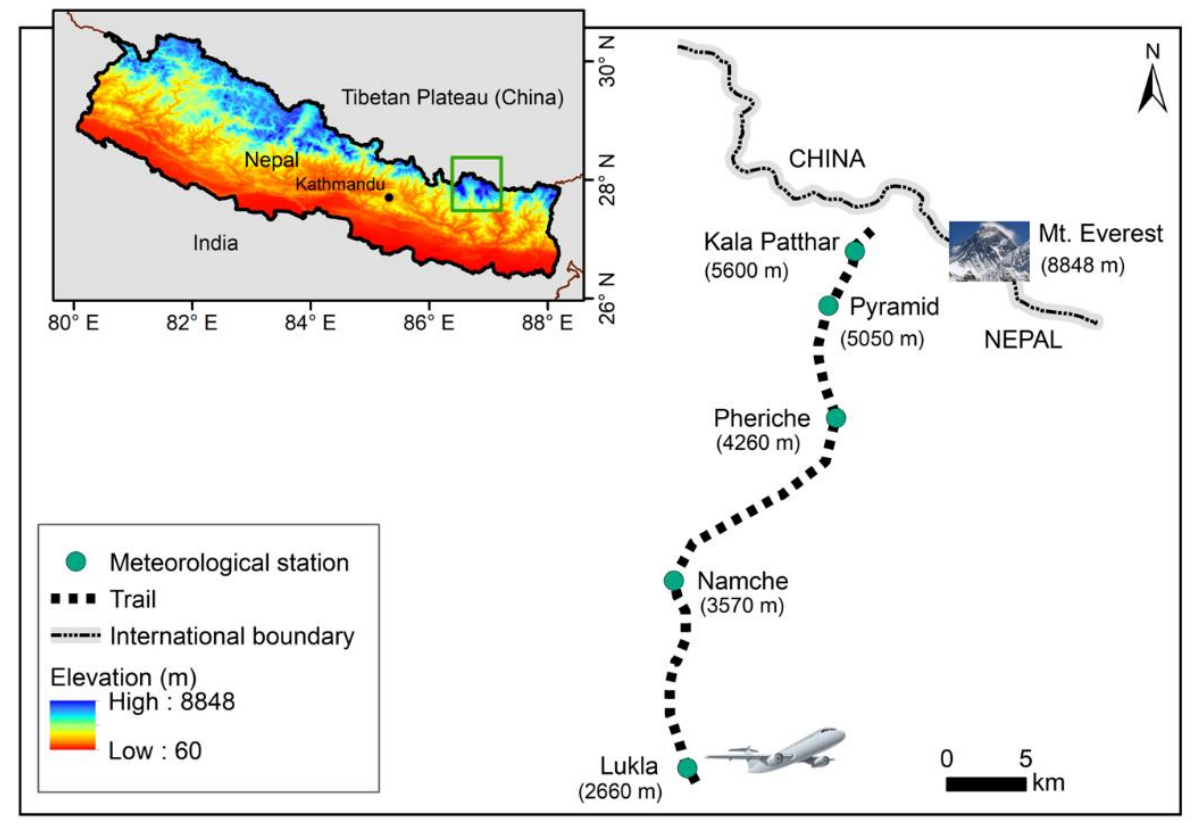

Figure 1. Map of Nepal (inset) showing the location of automatic weather stations (AWS) in different elevations along the southern slope of Mt. Everest.

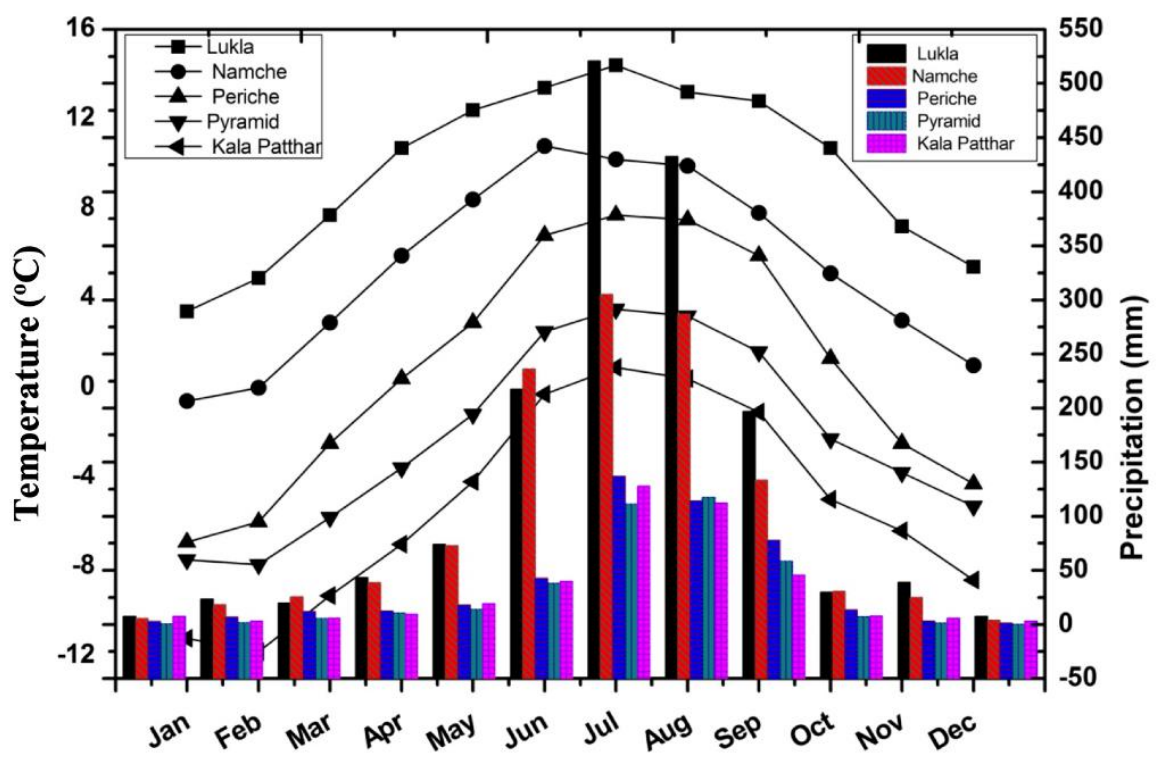

Figure 2. Climatology in the selected five high-elevation meteorological stations. The bar graph and line plot represent the precipitation and temperature, respectively. 
Does the High Elevation Climate Along Mt. Everest can be Represented ...

Table 1. Parameters and data for selected five high-elevation meteorological stations.

\begin{tabular}{rcccccc}
\hline S. N. & Station & Latitude & Longitude & Altitude $(\mathbf{m})$ & $\begin{array}{c}\text { Average annual } \\
\text { temperature }\left({ }^{\circ} \mathbf{C}\right)\end{array}$ & $\begin{array}{c}\text { Mean annual } \\
\text { precipitation } \\
(\mathbf{m m})\end{array}$ \\
\hline 1 & Lukla & 27.695 & 86.723 & 2660 & 9.7 & 1612 \\
2 & Namche Bazar & 27.802 & 86.714 & 3570 & 5.4 & 1182 \\
3 & Pheriche & 27.895 & 86.818 & 4260 & 0.9 & 442 \\
4 & Pyramid & 27.959 & 86.813 & 5050 & -2.2 & 364.8 \\
5 & Kala Patthar & 27.99 & 86.83 & 5600 & -5.3 & 386 \\
\hline
\end{tabular}

The daily, 5-day, 10-day, and monthly records of temperature and precipitation from the AWS at the different elevations were compared from January 2003 to December 2012 (2009-2012 for Kala Patthar). Their mean values were checked by paired sample t-tests, the data distributions by two-sample Kolmogorov-Smirnov tests, standard deviation, and Pearson's correlations were used to measure the strength of the relationships among the temperature/precipitation records. Regression analyses were performed on the daily mean temperature and daily precipitation on a monthly timescale to quantify the relationship of climatic records between low and high elevations. Following the study of Liang et al. (2014) and Dawadi (2017), the intercepts and slopes of the regression models, together with the correlation $\left(\mathrm{R}^{2}\right)$ values, are used to evaluate the physical meanings and quality of the regression models. Further, regression analyses on the 5day, 10-day, and monthly mean temperature and total precipitation data were performed based on daily data. Further, data from the daily and 5-day average/sum of the temperature and precipitation were pulled out to analyze the climatic parameter's seasonal linkage between the different stations.

\section{RESULTS AND DISCUSSION}

The increasing precipitation is observed from January to July, whereas a gradual decreasing pattern is observed between August and December in all stations except Pyramid (Fig. 3a). The highest amount of precipitation is observed in August and the lowest in February for the Pyramid station (Fig. 2). Generally, annual precipitation is less in the higher elevation than the lower elevation; however, a comparison of monthly precipitation at Namche Bazar showed a higher amount of precipitation in March, June, and October than the corresponding lower elevation at Lukla. Pyramid (higher elevation station) receives less precipitation than the Pheriche except in August, whereas Kala Patthar shows a different result, i.e., precipitation in Kala Patthar is higher than its counterpart in Pyramid except for April, August, and September (Fig. 3a). A higher amount of precipitation in Kala Patthar is observed in January. Further, the Lukla station clearly showed the impact of westerly in the high altitude during the winter season (Fig. 3a). It is a fact that precipitation is characterized by the nature of the terrain, especially over the mountainous region of the country (Kansakar et al., 2004). Generally, higher precipitation is observed in the mid-elevation (between 1500-2000 m) areas of the country and decreases with increasing elevation (Sharma et al., 2020a).

The climate of the region is characterized by the pronounced seasonality of temperature. Daily mean temperature ranges from -2 to $18^{\circ} \mathrm{C}$ in Lukla, -8.14 to $18^{\circ} \mathrm{C}$ for Namche Bazar, -15.21 to $9.86^{\circ} \mathrm{C}$ for Pheriche, 18.09 to $5.97^{\circ} \mathrm{C}$ for Pyramid and -20.46 to $3.30^{\circ} \mathrm{C}$ for Kala Patthar (Fig. 3b). Further, stations at Lukla and Namche Bazar show the highest temperature difference in the month of October. It is interesting to note that Namche Bazar-Pheriche and Pyramid- Kala Patthar show the highest temperature difference in the winter season, whereas the highest difference is observed in the Pheriche-Pyramid station for the monsoon season. Furthermore, Kala Patthar and Lukla station showed the highest temperature difference in the month of April and the lowest in August (Fig. 3b).

Association of temperature and precipitation along with the elevation

The mean temperature between the stations in the different elevations is highly variable; however, their variation in higher elevation is very consistent with the corresponding lower elevation. For example, the daily, 5days, 10-days, and monthly mean temperature and standard deviation are almost identical (Table 2). The correlation of mean temperature between the stations at a lower elevation with their corresponding higher elevation is up to $0.98(\mathrm{p}<0.0001, \mathrm{n}=3652)$ for the daily and 0.99 $(\mathrm{p}<0.0001, \mathrm{n}=120)$ for the monthly timescale. Further, the temperature correlation between the station at higher and lower elevation ranges from 0.87-0.99 ( $\mathrm{p}<0.0001, \mathrm{n}$ $=730)$ and $0.89-0.99(\mathrm{p}<0.0001, \mathrm{n}=365)$ for 5 -day temperature and 10-day temperature, respectively (Fig. 4). 
(a)

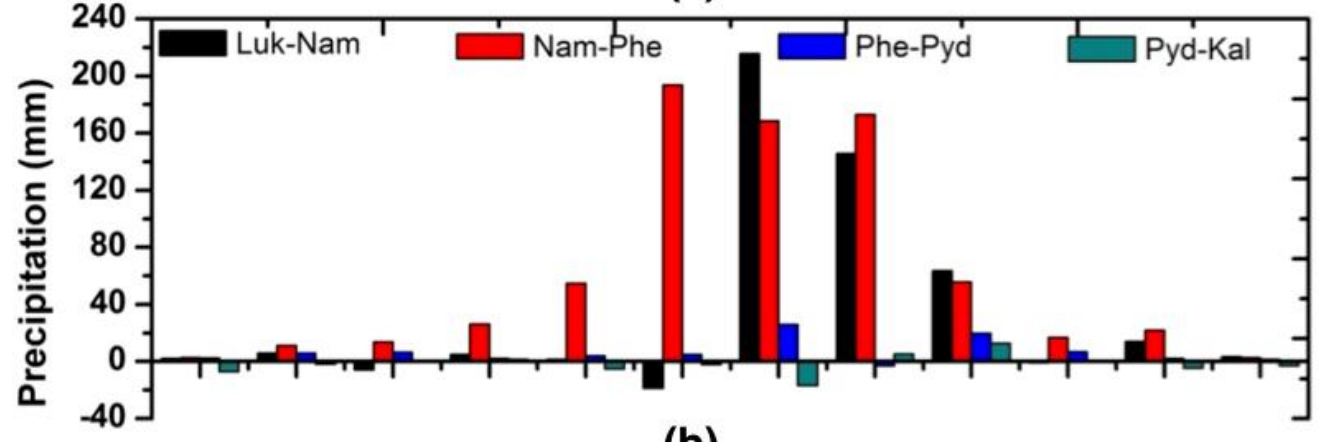

(b)

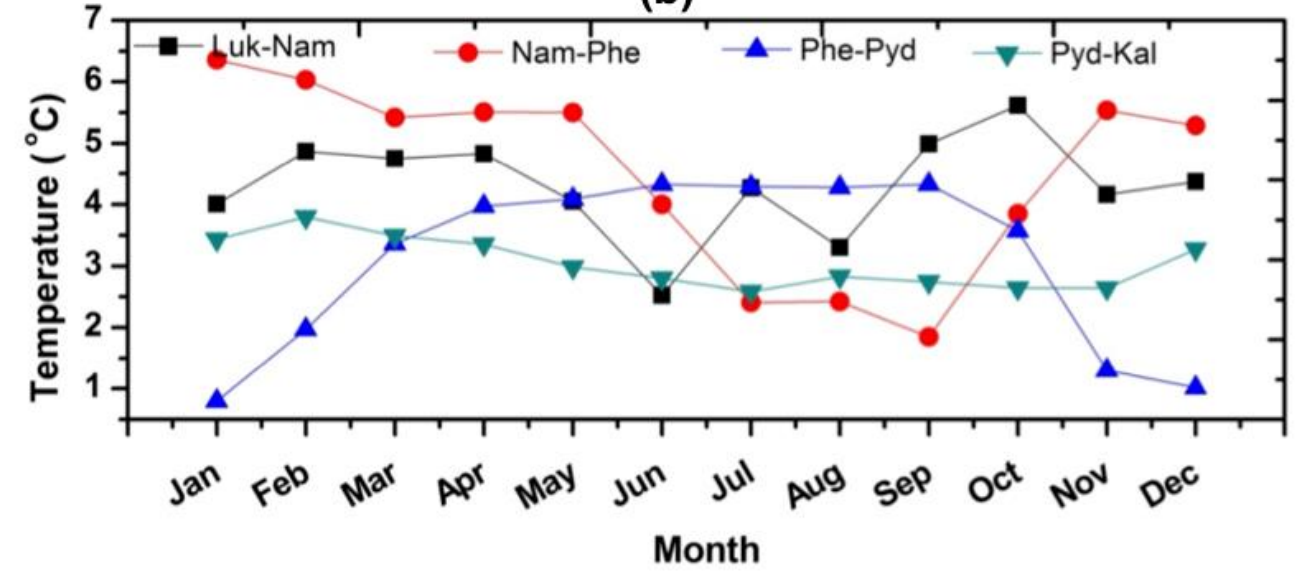

Figure 3. Precipitation (a) and temperature (b) difference between lower and higher elevation stations during the study period. Here, Luk, Nam, Phe, Pyd, and Kal denote the Lukla, Namche, Pheriche, Pyramid, and Kala Patthar station, respectively.

Table 2. Standard deviation and mean values of precipitation and temperature at different stations during the study period.

\begin{tabular}{llllll}
\multirow{2}{*}{ Parameter } & \multicolumn{5}{c}{ Standard deviation/mean values } \\
\cline { 2 - 6 } & Lukla & Namche & Pheriche & Pyramid & Kala Patthar \\
\hline Daily mean temperature $\left({ }^{\circ} \mathrm{C}\right)$ & $4.55 / 9.43$ & $4.9 / 5.15$ & $5.52 / 1.11$ & $4.74 /-2.26$ & $4.93 /-5.34$ \\
5-day mean temperature $\left({ }^{\circ} \mathrm{C}\right)$ & $3.91 / 9.44$ & $4.2 / 5.18$ & $4.8 / 1.07$ & $3.9 /-2.24$ & $4.1 /-5.31$ \\
10-day mean temperature $\left({ }^{\circ} \mathrm{C}\right)$ & $3.87 / 9.57$ & $4.13 / 5.27$ & $4.7 / 1.12$ & $3.8 /-2.18$ & $4.3 /-5.63$ \\
Monthly mean temperature $\left({ }^{\circ} \mathrm{C}\right)$ & $3.76 / 9.72$ & $3.97 / 5.23$ & $4.62 / 0.97$ & $3.55 /-2.15$ & $3.96 /-5.63$ \\
Daily precipitation $(\mathrm{mm} /$ day) & $10.94 / 4.72$ & $10.05 / 3.09$ & $2.91 / 1.26$ & $2.61 / 1.06$ & $2.84 / 1.09$ \\
5-day Precipitation $(\mathrm{mm} /$ day) & $42.26 / 22.53$ & $37.44 / 15.20$ & $10.05 / 6.12$ & $9.90 / 5.28$ & $9.63 / 5.12$ \\
10- day precipitation $(\mathrm{mm} /$ day) & $29.31 / 13.40$ & $24.63 / 4.09$ & $6.90 / 3.08$ & $6.53 / 2.37$ & $6.01 / 2.26$ \\
Monthlyprecipitation $(\mathrm{mm} /$ day) & $221.37 / 129.87$ & $194.96 / 97.03$ & $48.25 / 35.74$ & $49.00 / 30.54$ & $48.75 / 31.95$ \\
\hline
\end{tabular}



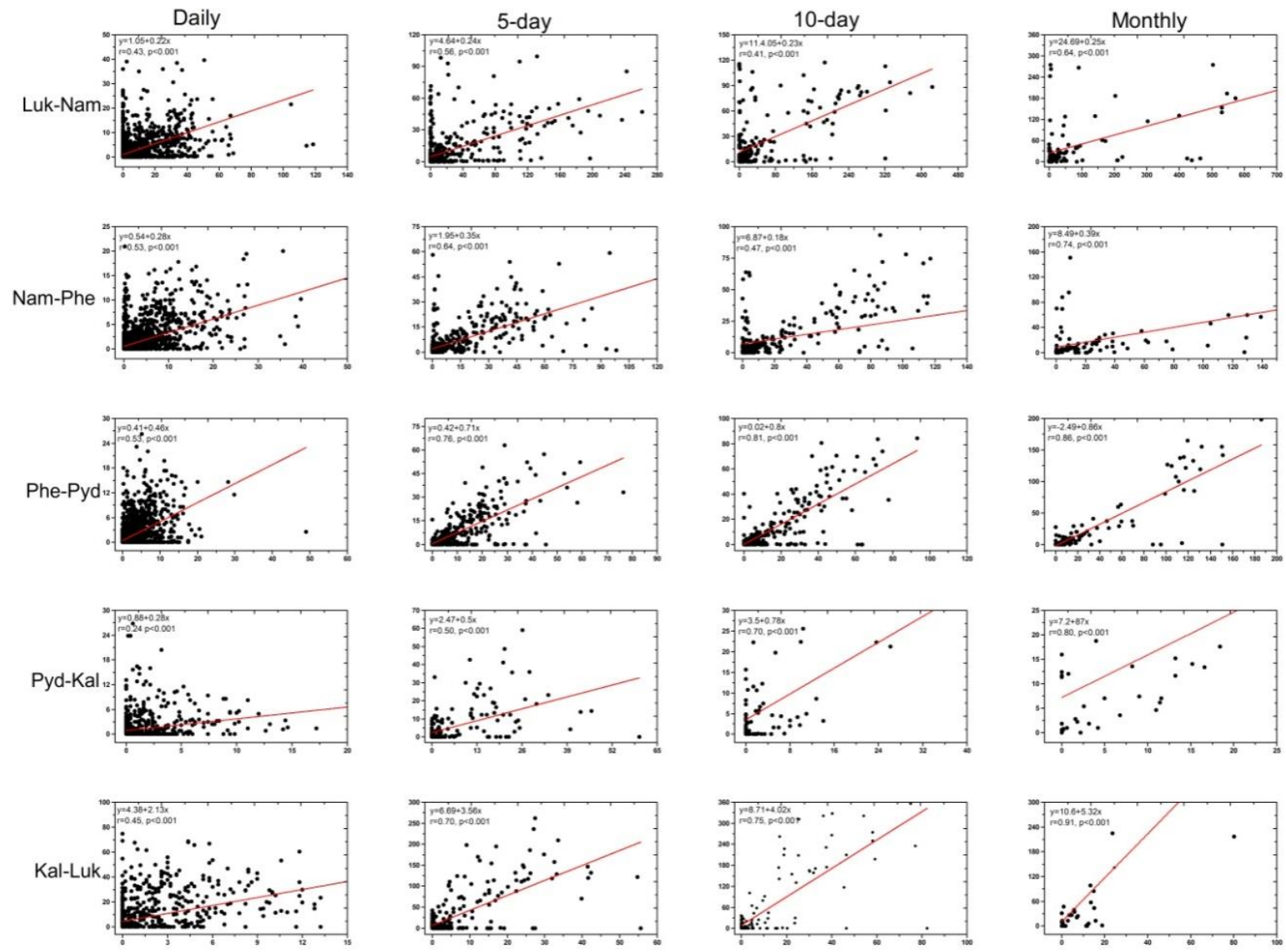

Figure 4. The temperature correlation between the station at higher and lower elevations ranges for daily, 5-day, 10-day, and monthly time scales during the study period.

Despite a lesser agreement in the standard deviation of precipitation data between higher and lower elevations (Table 2), the variations in the daily, 5-days, 10-days, and monthly precipitation at different altitudes were significantly correlated with their values at the corresponding stations (Fig. 5). The standard deviation in Table 2 further shows the small agreement in precipitation between higher and lower elevation stations compared to temperature records (Fig.s 4 and 5). Further, the variations in the daily, 5-days, 10-days, and monthly precipitation at different altitudes are also significantly correlated to each other (Fig. 5). The correlations increased with increasing lengths of the time intervals, up to 0.53 for the daily to 0.76 for 5-day, 0.81 for 10-day, and 0.91 for monthly timescale during the study period (Fig. 5). It is worth noting that the linear regression of temperature and precipitation in Figures 4 and 5 is statistically significant at 0.001 confidence level.

\section{Lower elevation temperature data to represent higher} elevation climate

Figure 6 presents the intercepts, slopes, and correlation $\left(\mathrm{R}^{2}\right)$ values of regression analysis based on the higher elevation data against the corresponding lower elevation for daily and 5-day temperature data pooled by individual months. It is interesting to note that for a one-degree change in Lukla temperature, there is more than a degree change in temperature in the winter season and in the month of April, June, and October (Fig.6a, b). However, during the rainy months (July, August, and September), the temperature in Namche Bazar is changed by $<0.54^{\circ} \mathrm{C}$ per degree changes in Lukla temperature. When there is a one-degree change in Lukla temperature, Namche temperature changes by $1.32^{\circ} \mathrm{C}$ in the month of January; this considerable temperature variation might be related to the large temperature difference between those stations in the particular month. In January, Lukla's temperature never became positive, whereas Namche almost always has a negative temperature. 

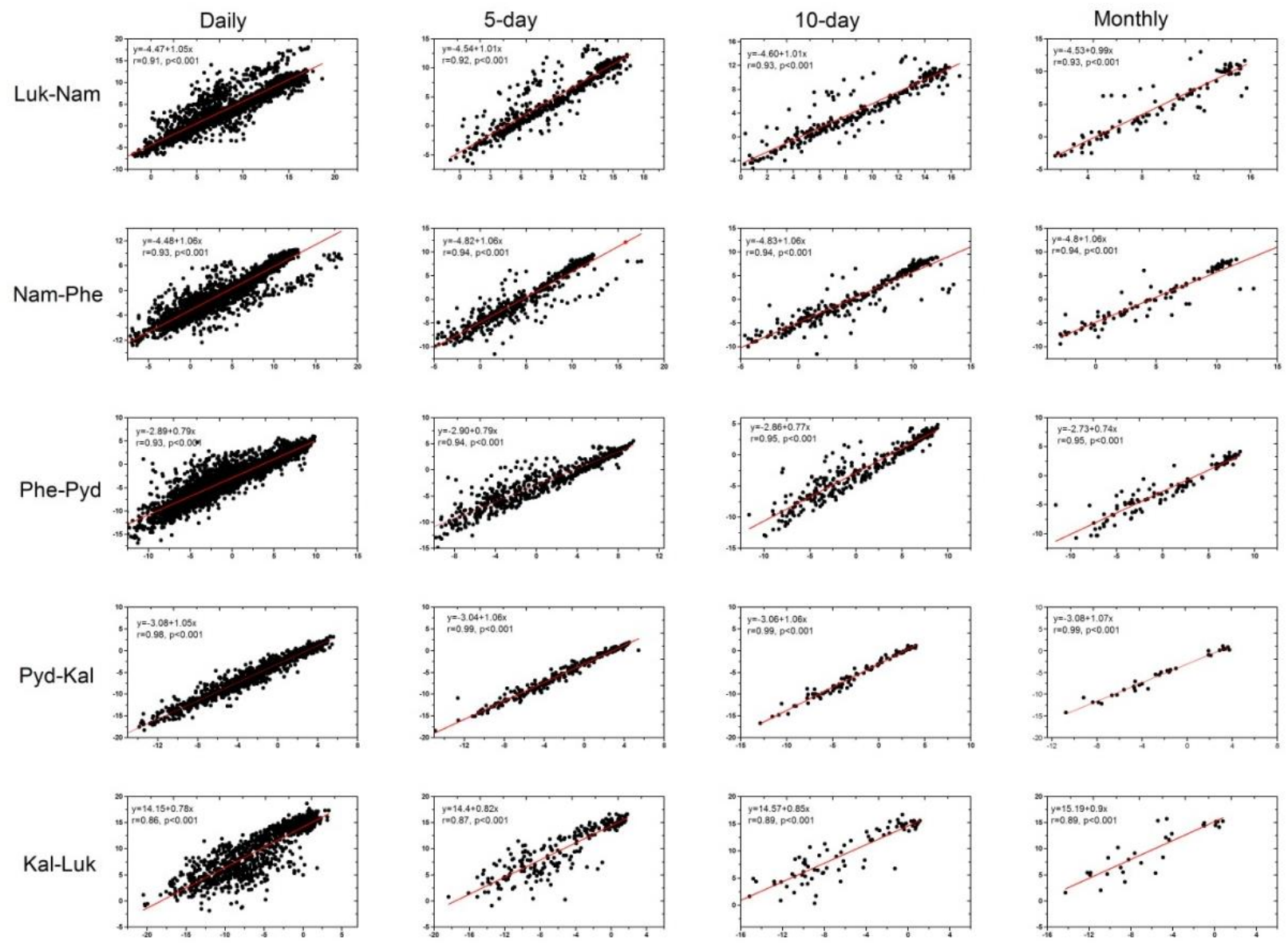

Figure 5. The precipitation correlation between the station at higher and their corresponding lower elevation ranges for daily, 5-day, 10-day, and monthly time scales during the study period.

In the Figure 6c and 6d, one-degree change in Namche temperature, Pheriche temperature varied by 0.27 to $0.95^{\circ} \mathrm{C}$ except in February. A similar range of change in temperature $\left(1^{\circ} \mathrm{C} / 1^{\circ} \mathrm{C}\right)$ is also observed between these two stations in the month of February. Comparison of temperature variation between Pheriche and Pyramid showed a very similar pattern, i.e., for a degree change in Pheriche temperature, there is also a similar variation (0.9 to $1.12^{\circ} \mathrm{C}$ ) in the months of December to May; however, decrease with the onset of monsoon in July, and the temperature variation start to increase in the month of October after the retreat of the monsoon (Figs. 6e and f). The Pyramid temperature is positive in monsoon months, whereas Pheriche temperature becomes positive from May to October. The negative minimum temperature is observed in the Pyramid station throughout the year, whereas the positive minimum temperature was observed in July and August at Pheriche station. The one-degree change in minimum temperature in July and August for Pyramid is 0.41 , which is 0.24 for Pheriche station with $\mathrm{R}^{2}>$ 0.42 (Figs. 6e and 6f).
The temperature variation in the high-altitude stations at Pyramid and Kala Patthar showed a similar range of variation throughout the year (Fig. $6 \mathrm{~g}$ and $\mathrm{h}$ ). There is an increase or decrease in Kala Patthar temperature by 0.82 to 1.13 per degree change in the corresponding lower elevation at the Pyramid station. The higher correlation $\left(\mathrm{R}^{2}>0.75\right)$ throughout the year between Pyramid and Kala Patthar further proves the reliability of the model (Fig. $5 \mathrm{~g}$ and $5 \mathrm{~h}$ ). It is interesting to note that during the half-year (December- May), Kala Patthar temperature also changes by $\sim 1^{\circ} \mathrm{C}$ per degree change in Pyramid temperature. Among all, the highest temperature variation was observed between Kala Patthar (5600) and Lukla station (2650 m asl) (Fig. 6i and 6j). However, both stations showed a similar range of variability of the daily and 5-day mean temperature during January and February. Only a small change $\left(0.21^{\circ} \mathrm{C}\right)$ was found in the Lukla station for a one-degree temperature change in Kala Patthar station during March. Although a small change was found in March, however in April, May, and June, the Lukla temperature changed up to $1.49^{\circ} \mathrm{C}$ for a one-degree change in Kala Patthar station (Fig.6i and j). Further, in 
March and November, a one-degree temperature change in Kala Patthar led to a temperature change in Lukla by 0.21 and $0.15^{\circ} \mathrm{C}$, respectively. Furthermore, a negative $\mathrm{R}^{2}$ value between these two stations indicates an opposite behavior of the temperature during March and November. Similarly, Maskey et al. (2011) also found negative correlations between snow cover and temperature, particularly in snow-free months, such as January and November for the elevation zones below $6000 \mathrm{~m}$.

Moreover, the variations in the daily and 5-day mean temperatures in the lower-elevation stations can represent their counterparts at the higher elevation stations (mainly in the high altitudes) at the southern slope of Mt Everest (Central Himalaya), supporting our hypothesis (Fig. 6). However, the relationships of different climatic parameters between the station are not consistent, and further corrections are necessary when the higher elevation environment needs to replicate accurately using the lower elevation data. Moreover, the regression models' intercepts for temperature indicate a hypothetical "base temperature" at a higher elevation when the corresponding lower elevation temperature is $0^{\circ} \mathrm{C}$. Moreover, the models' slopes showed the temperature changes at the higher elevation per ${ }^{\circ} \mathrm{C}$ measured at the lower elevation climatic station. Further, when the sun is shining in the low-elevation areas, it may be quite warm, even in winter, but the temperature drops rapidly in highelevation areas if a passing cloud blocks the sun. This might be the reason for the higher fluctuation of temperature during the winter season in the high-elevation station compared with their corresponding lower elevation stations (Dawadi et al., 2020). Furthermore, decreasing cloudiness and consequent increasing of daytime shortwave and decreasing of nighttime longwave incoming solar radiation may lead to temperature variation in higher and their corresponding lower elevation station (Thakuri et al., 2019).
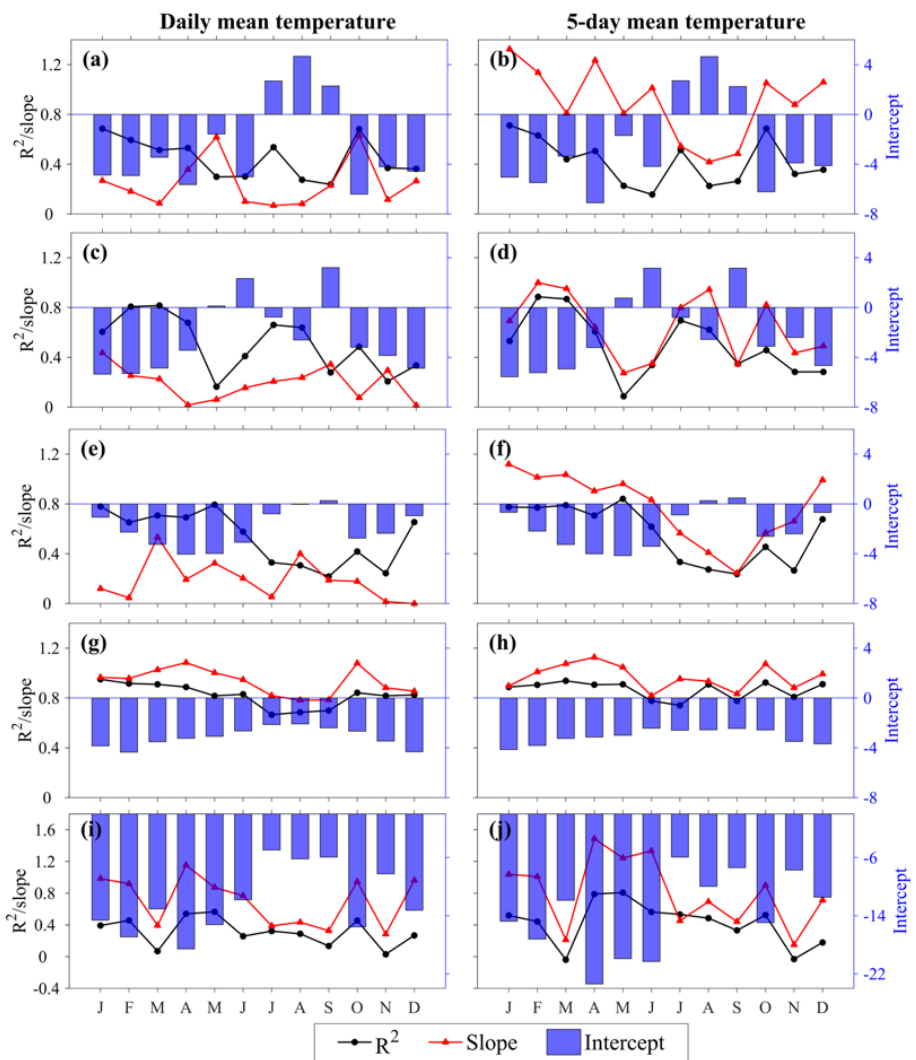

Figure 6. Monthly variation in correlation, slope, and intercept based on daily and 5-day mean temperature for (a, b) LuklaNamche, (c, d) Namche-Pheriche, (e, f) Pheriche-Pyramid, (g, h) Pyramid-Kala Patthar, and (i, j) Kala Patthar-Lukla station.

Precipitation linkage between the different elevations Figure 7 represents the monthly variation in correlation, slope, and intercept based on daily and 5-day total precipitation for lower elevation and their corresponding higher elevation stations during the study period. The intercept of the regression models for precipitation shows the amount of precipitation at lower/higher elevation when no precipitation is observed at the corresponding 
higher/lower elevation. The lower elevation station (i.e., Lukla) did not observe any precipitation events; however, corresponding higher elevation Namche observed $83 \mathrm{~mm}$ of rain during monsoon season (Fig.7a and b). From June to September, the high intercept values indicate the higher degree of frequencies of the rainfall between the stations during these months. In contrast, Namche station received up to $19 \mathrm{~mm}$ of rainfall when there was no rainfall at the corresponding Pheriche station (Fig.7c and d). About $8 \mathrm{~mm}$ of precipitation was observed at the Pheriche station when there is very light precipitation in the corresponding high-elevation station (i.e., Pyramid) (Figs. 7e and 7f). Further, similar results are also observed between Prymid-Kala Patthar, Kala Patthar-Lukla stations
(Figs. $7 g-j$ ). Moreover, when data are pooled in different months for regression analyses, high intercept values were generally found from March to October, suggesting higher frequencies of light precipitation at the upper timberline than at the valley bottom. It is observed that Namche station recorded most of its precipitation at nighttime (especially after 14:00 UTC), whereas at Pyramid AWS, daytime precipitation exceeded the nighttime precipitation (Ueno \& Aryal, 2008). This altitudinal tendency of diurnal precipitation changes agreed with the characteristics of monsoon precipitation observed in the Himalayas by previous studies (Ueno, 1993; Dawadi et al., 2020), which might be the reason for variation in precipitation among the stations located in the different elevations.
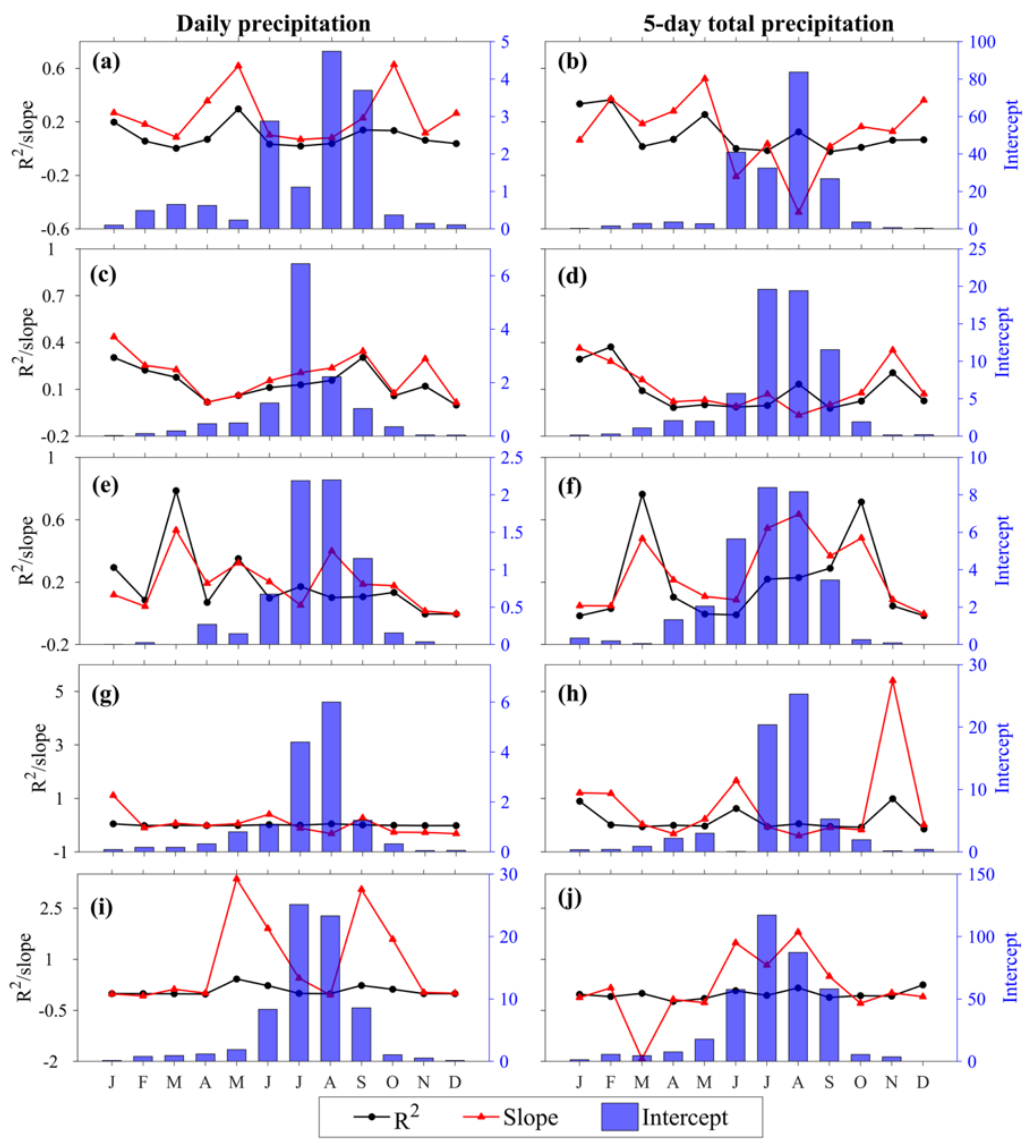

Figure 7. Monthly variation in correlation, slope, and intercept based on daily and 5-day total precipitation for (a, b) LuklaNamche, (c, d) Namche-Pheriche, (e, f) Pheriche-Pyramid, (g, h) Pyramid-Kala Patthar, and (i, j) Kala Patthar-Lukla station.

\section{CONCLUSIONS}

The Central Himalaya region is a data-scarce region, and most of the climatological studies in these regions are based on low-elevation observations. On this note, this study investigates the climatic linkage between stations at different elevations along the southern slope of Mt.
Everest. To do this, five climatic records ranging from $2660 \mathrm{~m}$ to $5600 \mathrm{~m}$ between January 2003 and December 2012 were compared. In terms of magnitude, means and distributions of temperature and precipitation in the different altitudes are significantly different from each other. Besides these differences, temperature and 
precipitation variation is consistent between the stations in the different altitudes, and their correlation increases with increasing time window.

A strong temperature correlation was observed between lower-elevation stations and their corresponding highelevation station. Similarly, the slopes of the regression model $\sim 1$ with $\left(\mathrm{R}^{2}>0.5\right)$ further indicate a similar change in temperature between the stations at a higher elevation to the corresponding lower elevation station. Moreover, the variations in the spatial and temporal difference in the regression model's slope further indicate that the temperature data from a lower elevation can be used to describe the climatic scenario of the high-elevation areas. It is worth mentioning that monthly temperature records at the lower elevation were a better representative for the corresponding station at the higher elevation. In contrast, the precipitation association between the stations at different elevations is not as strong as the temperature due to heterogeneous topographical features and steep altitudinal variation. However, some corrections are recommended when absolute temperature values are considered. Although the study period is only 10 years, this study will be helpful for understating the linkage of climatic records between lower and corresponding highest elevation meteorological stations from the world's highest mountain.

\section{ACKNOWLEDGEMENTS}

The authors would like to express their sincere gratitude to the EvK2-CNR Committee for providing the AWS station datasets.

\section{AUTHOR CONTRIBUTIONS}

BD developed the concept and wrote the original draft. SS, NK, KH, YPD, and SKM contributed to writing, reviewing and improving the manuscript. BD compiled all the figures and analysis with significant help from $\mathrm{KH}$, SS and NK.

\section{CONFICT OF INTERESTS}

The authors declare no conflict of interest.

\section{DATA AVAILABILITY STATEMENT}

The daily data sets for all the stations used in this study are provided by EvK2-CNR Committee upon request (http://www.evk2cnr.org/cms/en/research/integrated_p rograms/share).

\section{REFERENCES}

Beniston, M. (2003). Climatic change in mountain regions: a review of possible impacts, Climate Change, 59, 5-31.

Bohner, J. (2006), General climatic controls and topoclimatic variations in Central and High Asia, Boreas, 35(2), 279-295.

Chalise, S.R., \& Khanal, N.R. (2002). Recent extreme weather events in the Nepal Himalayas. The Extremes of the Extremes: Extraordinary Floods, 271, 141-146.
Dawadi, B. (2017). Climatic records and linkage along an altitudinal gradient in the southern slope of Nepal Himalaya. Journal of Nepal Geological Society, 53, 47-56.

Dawadi, B., Acharya, R.H., Lamihhane, D., Pudasainee, S., \& Shrestha, I.K. (2020). A short note on linkage of climatic records between Terai and Mid-mountain of central Nepal. Journal of Geographical Research, 3(4), 29-35.

Dawadi, B., Liang, E., Tian, L., Devkota, L.P., \& Yao, T. (2013). Pre-monsoon precipitation signal in tree rings of timberline Betula utilis in the central Himalayas. Quaternary International, 283, 72-77.

Dibike, Y., Prowse, T., Shrestha, R., \& Ahmed, R. (2012), Observed trends and future projections of precipitation and air temperature in the Lake Winnipeg watershed. Journal of Great Lakes Research, 38, 72-82.

Hamal, K., Khadka, N., Rai, S., Joshi, B.B., Dotel, J., Khadka, L., Bag, N., Ghimire, S.K., \& Shrestha, D. (2020a). Evaluation of the TRMM product for spatio-temporal characteristics of precipitation over Nepal (1998-2018), Journal of Institute of Science and Technology, 25(2), 39-48.

Hamal, K., Sharma, S., Baniya, B., Khadka, N., \& Zhou, X. (2020b). Inter-annual variability of winter precipitation over Nepal coupled with ocean-atmospheric patterns during 19872015. Frontiers in Earth Science, 8, 161. doi:10.3389/feart.2020 .00161 .

Hamal, K., Sharma, S., Khadka, N., Baniya, B., Ali, M., Shrestha, M.S., Xu, T., Shrestha, D., \& Dawadi, B. (2020c). Evaluation of MERRA-2 precipitation products using gauge observation in Nepal, Hydrology, 7(3), 40. doi:10.3390/hydrology7030040.

Kansakar, S.R., Hannah, D.M., Gerrard, J., \& Rees, G. (2004). Spatial pattern in the precipitation regime of Nepal, International Journal of Climatology, 24(13), 1645-1659. doi:10.10 02/joc.1098.

Karki, R., Hasson, S.U., Schickhoff, U., Scholten, T., \& Böhner, J. (2017). Rising precipitation extremes across Nepal. Climate, 5(1), 4. doi:10.3390/cli5010004.

Kattel, D., Yao, T., Yang, K., Tian, L., Yang, G., \& Joswiak, D. (2013). Temperature lapse rate in complex mountain terrain on the southern slope of the central Himalayas. Theoretical and Applied Climatology, 113(3-4), 671-682.

Khadka, N., Chen, X., Yong, N., Thakuri, S., Zheng, G., \& Zhang, G. (2020a). Evaluation of glacial lake outburst flood susceptibility using multi-criteria assessment frame-work in Mahalangur Himalaya. Frontiers in Earth Science, 8, 748.

Khadka, N., Ghimire, S.K., Chen, X., Thakuri, S., Hamal, K., Shrestha, D., \& Sharma, S. (2020b). Dynamics of maximum snow cover area and snow line altitude across Nepal (20032018) using improved MODIS data. Journal of Institute of Science and Technology, 25(2), 17-24.

Khadka, N., Zhang, G., \& Thakuri, S. (2018). Glacial lakes in the Nepal Himalaya: Inventory and decadal dynamics (19772017). Remote Sensing, 10(12), 1913.

King, O., Quincey, D.J., Carrivick, J.L., \& Rowan, A.V. (2017). Spatial variability in mass loss of glaciers in the Everest region, central Himalayas, between 2000 and 2015. The Cryosphere, 11(1), 407-426.

Krishnan, R., Shrestha, A.B., Ren, G., Rajbhandari, R., Saeed, S., Sanjay, J., Syed, M.A., Vellore, R., Xu, Y., \& You, Q. (2019). Unravelling climate change in the Hindu Kush Himalaya: rapid warming in the mountains and increasing extremes. In P. Wester, A. Mishra, A., Mukherji, \& A. Shrestha (Eds.), The Hindu Kush Himalaya Assessment (pp. 57-97), Springer.

Li, D., Yang, K., Tang, W., Li, X., Zhou, X., \& Guo, D. (2020). Characterizing precipitation in high altitudes of the western 
Tibetan plateau with a focus on major glacier areas. International Journal of Climatology, 40(12), 5114-5127. doi:10.10 02/joc.6509.

Li, Q., Chen, Y., Shen, Y., Li, X., \& Xu, J. (2011). Spatial and temporal trends of climate change in Xinjiang, China. Journal of Geographical Sciences, 21(6), 1007.

Liang, E., Dawadi, B., Pederson, N., \& Eckstein, D. (2014). Is the growth of birch at the upper timberline in the Himalayas limited by moisture or by temperature? Ecology, 95(9), 24532465.

Liang, F., Brook, G.A., Kotlia, B.S., Railsback, L.B., Hardt, B., Cheng, H., Edwards, R.L., \& Kandasamy, S. (2015). Panigarh cave stalagmite evidence of climate change in the Indian Central Himalaya since AD 1256: Monsoon breaks and winter southern jet depressions. Quaternary Science Reviews, 124, 145161.

Liu, X., \& Chen, B. (2000), Climatic warming in the Tibetan Plateau during recent decades. International Journal of Climatology: A Journal of the Royal Meteorological Society, 20(14), 1729-1742.

Maskey, S., Uhlenbrook, S., \& Ojha, S. (2011). An analysis of snow cover changes in the Himalayan region using MODIS snow products and in-situ temperature data. Climatic Change, 108(1-2), 391.

Poudel, A., Cuo, L., Ding, J., \& Gyawali, A.R. (2020). Spatio-temporal variability of the annual and monthly extreme temperature indices in Nepal. International Journal of Climatology, 40(11), 4956-4977.

Sabatini, F. (2017). Setting up and managing automatic weather stations for remote sites monitoring: from Niger to Nepal. In M. Tiepolo, A., Pessoli, \& V. Tarchiani (Eds.), Renewing Local Planning to Face Climate Change in the Tropics (pp. 21-39), Springer, Cham.

Salerno, F., Guyennon, N., Thakuri, S., Viviano, G., Romano, E., Vuillermoz, E., Cristofanelli, P., Stocchi, P., Agrillo, G., Ma, Y., \& Tartari, G. (2015). Weak precipitation, warm winters and springs impact glaciers of south slopes of Mt. Everest (central Himalaya) in the last 2 decades (1994-2013). Cryosphere, 9(3), 1229-1247.

Seidel, D.J., \& Free, M. (2003). Comparison of lowertropospheric temperature climatologies and trends at low and high elevation radiosonde sites. Climatic Change, 59, 53-74.

Sharma, S., Chen, Y., Zhou, X., Yang, K., Li, X., Niu, X., Hu, X., \& Khadka, N. (2020a). Evaluation of GPM-era satellite precipitation products on the southern slopes of the central Himalayas against rain gauge data. Remote Sensing, 12(11), 1836. doi:10.3390/rs12111836.

Sharma, S., Khadka, N., Hamal, K., Shrestha, D., Talchabhadel, R., \& Chen, Y. (2020b). How accurately can satellite products (TMPA and IMERG) detect precipitation patterns, extremities, and drought across the Nepalese Himalaya? Earth and Space Science, 7(8), e2020EA001315. doi:10.1029/2020ea00 1315.

Sharma, S., Khadka, N., Nepal, B., Ghimire, S.K., Luintel, N., \& Hamal, K. (2021). Elevation dependency of precipitation over southern slope of central Himalaya. Jalawaayu, 1(1), 1-14.

Shea, J., Immerzeel, W., Wagnon, P., Vincent, C., \& Bajracharya, S. (2015). Modelling glacier change in the Everest region, Nepal Himalaya. The Cryosphere, 9(3), 1105-1128.

Shrestha, A.B., \& Aryal, R. (2011). Climate change in Nepal and its impact on Himalayan glaciers. Regional Environmental Change, 11(1), 65-77.
Shrestha, A.B., \& Devkota, L.P. (2010). Climate change in the eastern Himalayas: observed trends and model projections, International Centre for Integrated Mountain Development (ICIMOD).

Shrestha, A.B., Wake, C.P., Dibb, J.E., \& Mayewski, P.A. (2000). Precipitation fluctuations in the Nepal Himalaya and its vicinity and relationship with some large scale climatological parameters. International Journal of Climatology, 20(3), 317-327.

Shrestha, D., Sharma, S., Hamal, K., Jadoon, U.K., \& Dawadi, B. (2021). Spatial Distribution of Extreme Precipitation Events and Its Trend in Nepal. Environmental Sciences, 9(1), 58-66.

Shrestha, S., Yao, T., \& Adhikari, T.R. (2019a). Analysis of rainfall trends of two complex mountain river basins on the southern slopes of the Central Himalayas. Atmospheric Research, 215, 99-115. doi:10.1016/.atmosres.2018.08.027.

Shrestha, S., Yao, T., Kattel, D.B., \& Devkota, L.P. (2019b). Precipitation characteristics of two complex mountain river basins on the southern slopes of the central Himalayas. Theoretical and Applied Climatology, 138(1-2), 1159-1178. doi:10.1007/00704-019-02897-7.

Sun, Q., Miao, C., Duan, Q., Ashouri, H., Sorooshian, S., \& Hsu, K.L. (2018). A review of global precipitation data sets: Data sources, estimation, and intercomparisons. Reviews of Geophysics, 56(1), 79-107. doi:10.1002/2017rg000574.

Talchabhadel, R., Karki, R., Thapa, B.R., Maharjan, M., \& Parajuli, B. (2018). Spatio-temporal variability of extreme precipitation in Nepal. International Journal of Climatology, 38(11), 4296-4313. doi:10.1002/joc.5669.

Thakuri, S., Dahal, S., Shrestha, D., Guyennon, N., Romano, E., Colombo, N., \& Salerno, F. (2019). Elevation-dependent warming of maximum air temperature in Nepal during 19762015. Atmospheric Research, 228, 261-269.

Thompson, L.G., Yao, T., Mosley-Thompson, E., Davis, M., Henderson, K., \& Lin, P.-N. (2000). A high-resolution millennial record of the South Asian monsoon from Himalayan ice cores. Science, 289(5486), 1916-1919.

Ueno, K., \& Aryal, R. (2008). Impact of tropical convective activity on monthly temperature variability during nonmonsoon season in the Nepal Himalayas. Journal of Geophysical Research: Atmospheres, 113(D18112). doi:10.1029/2007JD009524 .

Ueno, K.I. (1993). Precipitation environment in the Langtang Valley, Nepal Himalayas. LAHS Publ., 218, 207-219.

Wang, Y., Yang, K., Zhou, X., Chen, D., Lu, H., Ouyang, L., Chen, Y., \& Wang, B. (2020). Synergy of orographic drag parameterization and high resolution greatly reduces biases of WRF-simulated precipitation in central Himalaya. Climate Dynamics, 54(3), 1729-1740.

Xu, X., Frey, S.K., Boluwade, A., Erler, A.R., Khader, O., Lapen, D.R., \& Sudicky, E. (2019). Evaluation of variability among different precipitation products in the Northern Great Plains. Journal of Hydrology: Regional Studies, 24, 100608.

Yao, T., Thompson, L., Yang, W., Yu, W., Gao, Y., Guo, X., Yang, X., Duan, K., Zhao, H., \& Xu, B. (2012). Different glacier status with atmospheric circulations in Tibetan Plateau and surroundings. Nature Climate Change, 2(9), 663-667.

Yue, S., Yang, K., Lu, H., Chen, Y., Sharma, S., Yang, X., \& Shrestha. M.L. (2019). Distinct temperature changes between north and south sides of central-eastern Himalayas since 1970s. International Journal of Climatology, 40(9), 4300-4308. doi:10.1002/joc.6439. 